\title{
Optimization of Multigrain Premix for High Protein and Dietary Fibre Biscuits Using Response Surface Methodology (RSM)
}

\author{
Kathalsar Ashwath Kumar, Gopal Kumar Sharma*, Mohammed Ayub Khan, Anil Dutt Semwal \\ Cereals and Pulses Technology Division, Defence Food Research Laboratory, Siddarthanagar, Mysore, \\ Karnataka, India \\ Email: ${ }^{*}$ gksh60@gmail.com, ${ }^{*}$ ashwathk_rao@ymail.com
}

Received 23 April 2015; accepted 8 June 2015; published 11 June 2015

Copyright (C) 2015 by authors and Scientific Research Publishing Inc.

This work is licensed under the Creative Commons Attribution International License (CC BY). http://creativecommons.org/licenses/by/4.0/

c) (i) Open Access

\begin{abstract}
In order to improve the nutritional quality of biscuits, a multigrain premix (MGP) was developed by using whole barley, sorghum, chickpea, pea and defatted soya flour, each at $20 \%$ level. The developed MGP had $26.28 \%$ protein, $\mathbf{1 0 . 1 3 \%}$ insoluble dietary fiber and $7.38 \%$ soluble dietary fiber. The experiment was designed to optimise the MGP and wheat flour concentration for the development of multigrain biscuits with high protein, dietary fibre and to maximize the acceptability by the application of central composite rotatable design (CCRD) of Response Surface Methodology (RSM). The levels of incorporation of MGP and wheat flour were taken as variables whereas protein, soluble, insoluble fibers, biscuit dough hardness, breaking strength and overall acceptability (OAA) as responses. The optimum level of MGP and wheat flour obtained using numerical optimization was found to be $40 \mathrm{~g}$ and $60 \mathrm{~g}$ respectively. The biscuits prepared using these had $16.61 \%$ protein, $2.57 \%$ soluble fibre, and $6.67 \%$ insoluble fibre which is significantly $(p \leq 0.05)$ higher than control biscuit.
\end{abstract}

\section{Keywords}

Multigrain Biscuits, Breaking Strength, High Protein and Fiber, Multigrain Premix, Response Surface Methodology (RSM)

\section{Introduction}

In recent years, there is an increased demand for fiber and protein rich, nutritious ready-to-eat foods with ex-

${ }^{*}$ Corresponding author.

How to cite this paper: Kumar, K.A., Sharma, G.K., Khan, M.A. and Semwal, A.D. (2015) Optimization of Multigrain Premix for High Protein and Dietary Fibre Biscuits Using Response Surface Methodology (RSM). Food and Nutrition Sciences, 6, 747-756. http://dx.doi.org/10.4236/fns.2015.69077 
tended shelf life, satisfying taste and texture [1]. Among ready-to-eat foods, biscuits are one of the most popular, convenient food consumed both in urban and rural areas [2]. The basic formulation of biscuit contains wheat flour, sugar and fat apart from baking chemicals like baking powder, sodium bicarbonate and salt [3]. Wheat flour used in the biscuit making is refined wheat flour of 60 to $75 \%$ extraction in which the major portion of minerals, vitamins, fibres found in the bran layer is partially or totally removed [1]. Biscuits can be considered as a better vehicle for fortification and enrichment with protein and other vital nutrients, as it is popular among all age groups of the population [4]. Enrichment of biscuits by replacing the wheat flour with high protein ingredients such as pulses, oil seeds, protein concentrates, isolates and industrial by-products has been reported by many authors [5] [6].

The demand for fibre-enriched baked products to increase the consumption of dietary fibre and also to decrease the caloric density of the baked goods is getting importance [7]. Consumption of dietary fibre is associated with various health benefits like lowering of cholesterol, glycemic index level, colon cancer, bowel disorders and to improve lipid metabolism [8]. Use of grains or a combination of one or two grains, legumes, and oilseeds is a recent trend in the baking industry as it gives multiple health benefits apart from improved taste, aroma, appearance and variety [9]. Earlier, many authors have used protein and fibre rich ingredients to improve the nutritional quality of biscuits [3] [10]. Combination of cereals, pulses and oil seeds will give the combined effect of increased quality protein and dietary fibre in the end product [11].

Generally, optimization was done by means of varying one parameter while keeping the others at a constant level or varying both parameters. The main disadvantage of this method was that it does not include interactive effects among the other variables, and also does not represent the effects of various parameters on their responses [12]. RSM, which uses CCRD to fit a first- or second-order polynomial by a least significance technique, is used to optimize the variables (MGP and wheat flour) for the development of biscuits with high protein and dietary fibre [13]. The RSM technique gives the effect of an individual parameter as well as interactive effect of the parameters [14]. Earlier also, many authors have used RSM for food product development and process optimization [15]-[17].

There is no available report on the development of MGP and its optimization for biscuits. With the above background, considering the necessity of increasing both protein and dietary fibre ingestion and also keeping in mind the customers demand for healthier foods with high sensory quality, optimization of MGP for biscuit was carried out.

\section{Material and Methods}

\subsection{Raw Materials}

The grains like sorghum (Sorghum vulgare), barley (Hordeum vulgare L.), chickpea (Cicer arietinum), pea (Pisum sativum), commercial wheat flour (Double Nandi Brand), sugar, skimmed milk powder (Nandini brand, Karnataka Milk Federation, Mysore, India) and vanilla essence (Bush Boake Allen Ltd., Chennai, India) were procured from the local market, Mysore, India. The defatted toasted soya flour (Glycine max) was procured from Sakthi Soya Company, Pollachi, Tamil Nadu, India. Marvo pride brand bakery shortening for biscuit was procured from Bunge India Pvt. Ltd., Mumbai, India.

\subsection{Preparation of Multigrain Premix (MGP)}

The grains like sorghum, barley, chickpea and peas were cleaned and milled separately using an ultra-centrifugal mill (Retsch ZM 200, Germany) using $200 \mu \mathrm{m}$ sieve. The milled flours were packed separately in an airtight container and stored at $4^{\circ} \mathrm{C}$ for further use. Based on preliminary studies, MGP containing five different grains were selected and combined in the ratio of 1:1, to get maximum benefit of protein and dietary fiber in MGPs without adversely affecting the sensory characteristics of biscuits. All flours at 1:1 ratio were combined in a Hobart mixer (Model N50, Hobart Gmbh, Offenburg, Germany) and mixed for 10 min to get homogenous mix. The mixed MGP was sieved through $200 \mu \mathrm{m}$ sieve to get uniform particle size.

\subsection{Physico-Chemical Characteristics and Proximate Composition of MGP and Biscuits}

The moisture (method 44 - 16), protein (method 46 - 10), fat (method 30 - 10), ash content (method 08 - 01), dry gluten (method 38 - 10), falling number (method 56 - 81 B) were analyzed based on AACC methods [18] whe- 
reas the soluble and insoluble dietary fibres were estimated according to the method [19]. The carbohydrate content was calculated by the difference method $(100-\%$ moisture $+\%$ crude protein $+\%$ crude fat $+\%$ ash $+\%$ fiber). Energy content was calculated by multiplying protein, fat and carbohydrate contents by factors of 4, 9 and 4, respectively. The mean of three independent determinations was reported.

\subsection{Experimental Design}

A CCRD analysis was used to optimize and evaluate the effect of two variables (MGP and wheat flour) on responses (protein (\%), soluble fibre (\%), insoluble fibre (\%), dough hardness $(\mathrm{N})$, breaking strength $(\mathrm{N})$ and OAA). Based on previous preliminary baking experiments, the variable ranges were determined and presented with their coded and actual values in Table 1 . The proportion of each flour was expressed as a fraction of the mixture and for each treatment combination, the sum of the components proportion was equal to 100 ; where $x_{i}=x_{1}+x_{2}$ $=100 \%$.

The thirteen different experiments were carried out with four factorial points, five replicates of central points and four axial points and presented in Table 2. Experiments were conducted randomly to minimize the effect of unexplained variables in the observed responses due to extraneous factors [20].

The results for the CCRD were used to fit second-order polynomial equation. The regression analysis of the responses was conducted by fitting suitable models represented by (1) \& (2)

1) First order linear equation

$$
Y=\beta_{0}+\sum_{i=1}^{n} \beta_{i} X_{i}
$$

Table 1. Experimental ranges and levels of variables used in RSM in terms of actual and coded factors.

\begin{tabular}{cccccc}
\hline & \multirow{2}{*}{ Variables } & \multicolumn{4}{c}{ Range of levels } \\
\cline { 3 - 6 } & & Low actual & Low coded & High actual & High coded \\
\hline A & MGP (\%) & 10.00 & -1.000 & 40.00 & 1.000 \\
B & Wheat flour (\%) & 60.00 & -1.000 & 90.00 & 1.000 \\
\hline
\end{tabular}

Table 2. Experimental design and responses for high protein and dietary fibre enriched biscuits.

\begin{tabular}{|c|c|c|c|c|c|c|c|c|}
\hline \multirow{2}{*}{$\begin{array}{l}\text { Assay } \\
\text { number }\end{array}$} & \multicolumn{2}{|c|}{ Variables } & \multicolumn{6}{|c|}{ Responses } \\
\hline & $\begin{array}{l}\text { MGP } \\
(\%)\end{array}$ & $\begin{array}{l}\text { Wheat flour } \\
\text { (\%) }\end{array}$ & $\begin{array}{l}\text { Protein } \\
(\%)\end{array}$ & $\begin{array}{c}\text { Soluble } \\
\text { fibre (\%) }\end{array}$ & $\begin{array}{l}\text { Insoluble } \\
\text { fibre (\%) }\end{array}$ & $\begin{array}{c}\text { Dough } \\
\text { hardness }(\mathrm{N})\end{array}$ & $\begin{array}{l}\text { Biscuit breaking } \\
\text { strength }(\mathrm{N})\end{array}$ & $\begin{array}{l}\text { OAA } \\
(9)\end{array}$ \\
\hline 1 & +1.414 & 0 & 16.35 & 2.21 & 6.32 & 378.13 & 21.17 & 7.9 \\
\hline 2 & +1 & -1 & 17.01 & 2.51 & 6.82 & 385.21 & 22.2 & 7.9 \\
\hline 3 & -1 & -1 & 8.34 & 0.74 & 241.77 & 241.77 & 8.71 & 8.5 \\
\hline 4 & 0 & -1.414 & 13.94 & 2.11 & 5.13 & 275.19 & 14.47 & 7.8 \\
\hline 5 & 0 & 0 & 12.37 & 1.38 & 4.89 & 331.22 & 16.87 & 8.2 \\
\hline 6 & 0 & 0 & 11.97 & 1.5 & 4.78 & 338.22 & 15.98 & 8.2 \\
\hline 7 & 0 & 0 & 11.87 & 1.41 & 4.9 & 335.23 & 16.49 & 8.2 \\
\hline 8 & 0 & 0 & 12.47 & 1.4 & 4.96 & 338.43 & 16.67 & 8.2 \\
\hline 9 & +1 & +1 & 14.31 & 1.98 & 5.27 & 345.37 & 15.38 & 8.0 \\
\hline 10 & -1.414 & 0 & 5.71 & 0.41 & 1.13 & 254.43 & 9.84 & 8.8 \\
\hline 11 & 0 & +1.414 & 12.21 & 1.49 & 3.42 & 310.68 & 14.81 & 8.3 \\
\hline 12 & -1 & +1 & 6.21 & 0.57 & 1.87 & 283.09 & 12.16 & 8.7 \\
\hline 13 & 0 & 0 & 11.78 & 1.55 & 4.78 & 325.17 & 16.78 & 8.1 \\
\hline
\end{tabular}


2) Second order polynomial equation

$$
Y=\beta_{0}+\sum_{i=1}^{n} \beta_{i} x_{i}+\sum_{i=1}^{n} \beta_{i i} x_{i}^{2}+\sum_{i \neq j=1}^{n} \beta_{i i} x_{i} x_{i j}
$$

where, $\beta_{0}$ was the value of the fitted response at the center point of the design, i.e., point $(0,0,0)$ in case MGP and wheat flour; $x_{i}, x_{i j}$ were variables; $\beta_{i}, \beta_{i i}$ and $\beta_{i j}$ were regression coefficients and $\mathrm{n}$ denoted the number of variables.

The optimization of multigrain biscuits for protein and dietary fibre enrichment was performed according to the method [21] [22]. Design Expert 7.0.0 software (Stat Ease Inc., Minneapolis, MN) was used to generate the models that fit the experimental data, draw the response surface plots and Analysis of Variance (ANOVA) to obtain the coefficients of the final equation for better accuracy. Three-dimensional (3D) surface plots were drawn to illustrate the interactive effects. All the individual desirability functions obtained for each response were combined into an overall expression, which is defined as the geometrical mean of the individual functions. The higher the desirability value, the more adequate is the system. In this study, desirability functions were developed in order to obtain maximum protein, soluble fibre, insoluble fibre, OAA and minimize biscuit dough hardness and breaking strength. All variables of the polynomial regression at a significance level of $p \leq 0.05$ were included in the model, and the coefficient of determination $\left(\mathrm{R}^{2}\right)$ was generated in order to assess the adequacy of the model.

\subsection{Preparation of Biscuit}

Biscuits were prepared according to the AACC method 10 - 52 [18] with some modifications (Figure 1). The ingredients used for the preparation of biscuits were wheat flour $100 \mathrm{~g}$, pulverized sugar $35 \mathrm{~g}$, bakery shortening $20 \mathrm{~g}$, sodium chloride $0.5 \mathrm{~g}$, sodium bicarbonate $0.5 \mathrm{~g}$, ammonium bicarbonate $1 \mathrm{~g}$, skimmed milk powder $2 \mathrm{~g}$, dextrose $2 \mathrm{~g}$ and vanilla essence $1 \mathrm{ml}$. The same procedure was used for the development of multigrain biscuits except the replacement of wheat flour with MGP according to the experimental design and maintaining remaining ingredients constant for all the experiments. After cooling the biscuits were stored in airtight container for further analysis.

\subsection{Biscuit Dough Hardness}

The hardness of the biscuit dough for all the assays was measured using texture profile analysis (TPA) method [23] using a texture analyzer (TA-HD plus, Stable Micro Systems, Surrey, UK). The hardness of the biscuit dough was measured with $50 \mathrm{Kg}$ load cell. The following conditions were used: biscuit dough thickness, $10 \mathrm{~mm}$ (circular disc); diameter, $40 \mathrm{~mm}$; circular probe- $80 \mathrm{~mm}$ diameter; crosshead speed, $50 \mathrm{~mm} / \mathrm{min}$; compression$50 \%$ of dough height. The mean of three independent determinations was reported.

\subsection{Biscuit Breaking Strength}

The breaking strength of biscuit was determined by texture analyzer using triple beam snap (three point break) techniques as per method [24]. The peak force from the resulting curve indicated as the breaking strength of biscuits. The mean of three independent determinations was reported.

\subsection{Sensory Evaluation of Biscuits}

Sensory quality of multigrain biscuits (MGBs) was evaluated by twenty panellists of age between 25 to 50 years, including both male and female, who had earlier experience in quality evaluation of bakery products. They were further oriented in four sessions, including two hours of training in each session. The samples were evaluated in triplicates by each panellist for its overall acceptability on a 9 point hedonic scale $(1=$ dislike extremely, $5=$ neither like nor dislike and $9=$ like extremely) according to the method [25]. The samples were identified by code numbers and presented in a random order to the panellist.

\subsection{Statistical Analysis}

Data was analyzed by the least-squares method and response surfaces were generated using the Design Expert ${ }^{\circledR}$ 


\section{Creaming}

Pulverized sugar, Fat, Skimmed milk powder, dextrose, salt and vanilla

essence were combined in Hobart mixer and mixed with flat blade at $61 \mathrm{rpm}$

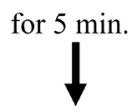

Baking Chemicals Addition

Sodium bicarbonate and Ammonium bicarbonate is dissolved separately in

water and added to homogenized cream and mixed at $125 \mathrm{rpm}$ for $5 \mathrm{~min}$.

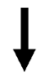

Mixing and Creaming with Flours

Wheat flour and MGP were added according to Experimental design (Table 2)

and mixed at $61 \mathrm{rpm}$ for $2 \mathrm{~min}$.

$\downarrow$

Dough Sheeting

The dough was sheeted to $3.5 \mathrm{~mm}$ thickness using stainless steel frame of 3.5

$\mathrm{mm}$

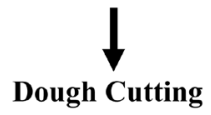

Uniformly sheeted dough was cut into circular shape using $55 \mathrm{~mm}$ cutter and

transferred to aluminium tray

$\downarrow$

Baking of Biscuits

3iscuits were baked in rotatable oven at $200^{\circ} \mathrm{C}$ for $10 \mathrm{~min}$ and cooled to room

temperature.

Figure 1. Flow chart for the preparation of biscuit.

7.0.0 software (Stat Ease Inc., Minneapolis, MN). Analysis of variance (ANOVA) was used to test the significance of each variable $(\mathrm{p} \leq 0.05)$ and to verify the adequacy of the model. Interaction effects were determined using LS means $(\mathrm{p} \leq 0.05)$. All experiments were carried out in triplicate.

\section{Results and Discussion}

\subsection{Flour Analysis}

The wheat flour used for the study contained $13.1 \%$ moisture, $0.5 \%$ ash, $10.3 \%$ protein, $9.9 \%$ dry gluten and 398 $\mathrm{s}$ falling number indicating thereby the wheat flour selected for the study was of medium strong quality. Earlier researcher [26] also used the wheat flour having $0.51 \%$ ash, $10.4 \%$ protein, $9.8 \%$ dry gluten and falling number of $428 \mathrm{~s}$ to prepare cookies with dried Moringa leaves. The developed MGP had 8.1\% moisture, 3.4\% ash, 26.3\% protein, $17.5 \%$ total dietary fiber $(7.4 \%$ soluble and $10.1 \%$ insoluble dietary fiber) which indicates its suitability to use in the development of protein and dietary fiber enriched biscuits. 


\subsection{Effect of Variables on the Selected Responses}

The 13 experimental combinations of CCRD with two selected variables were presented in Table 2. Incorporation of MGP significantly ( $\mathrm{x} \leq 0.05$ ) increased the protein, soluble and insoluble fibres content in biscuits. The increase in protein content is mainly due to the presence of defatted soya flour, chickpea and pea flour in the MGP. Particularly, soya is known for its rich protein content with high levels of lysine and other micronutrients [27]. Barley will contribute for soluble and insoluble dietary fibers, particularly soluble fiber component betaglucan, which is reported to lower cholesterol levels [8]. Sorghum with husk will contribute to soluble and insoluble fiber along with polyphenols, which results in the high fiber content in the MGP [28]. Figures 2(a)-(c)

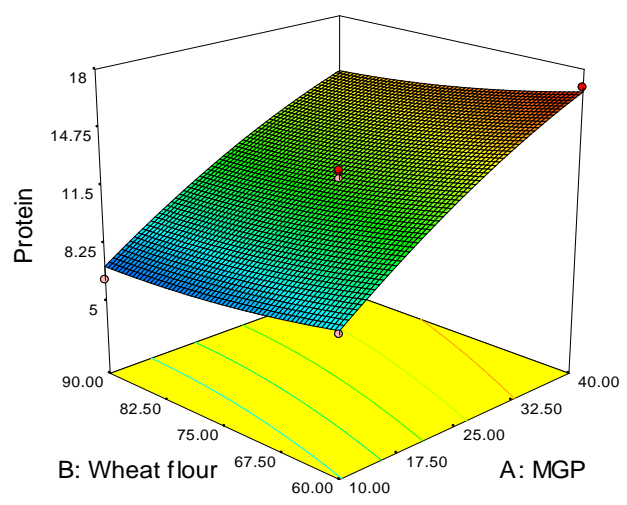

(a)

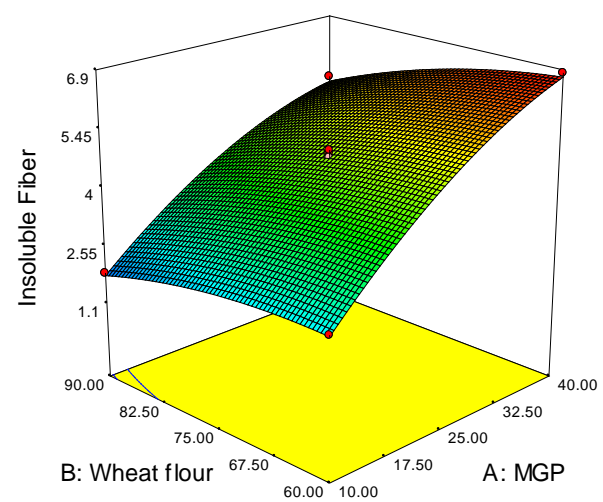

(c)

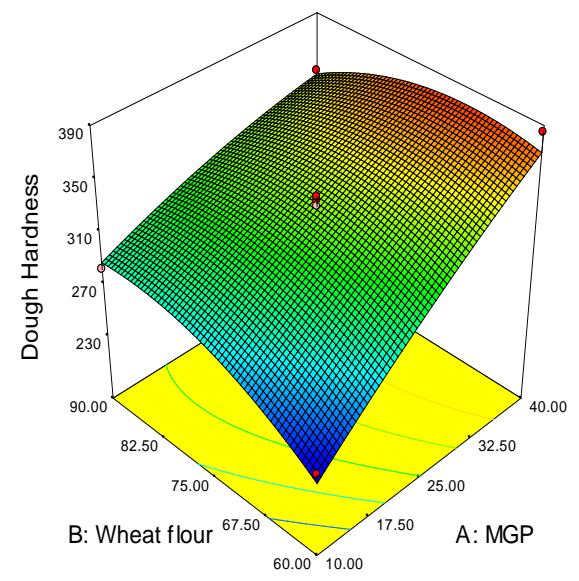

(e)

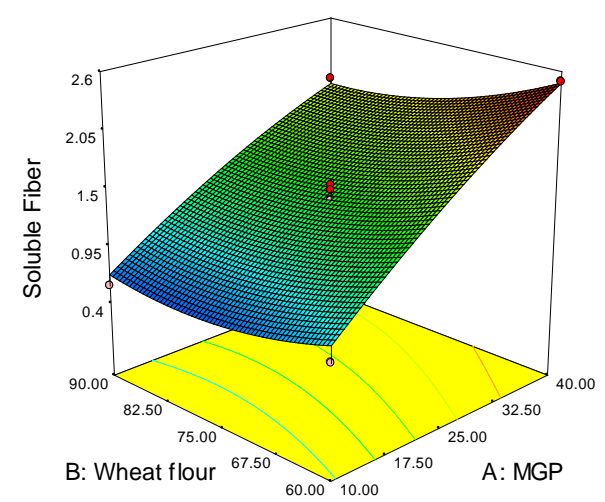

(b)

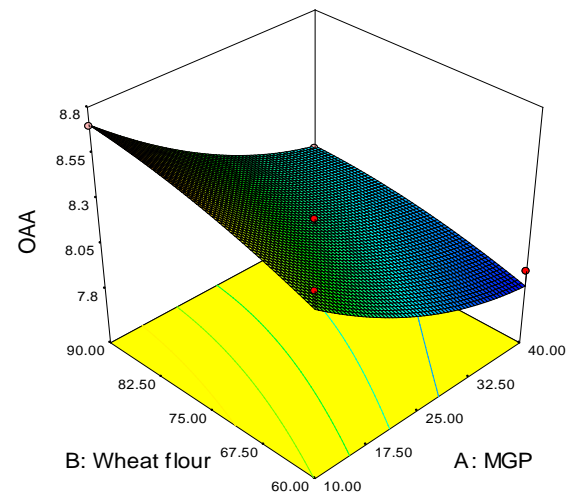

(d)

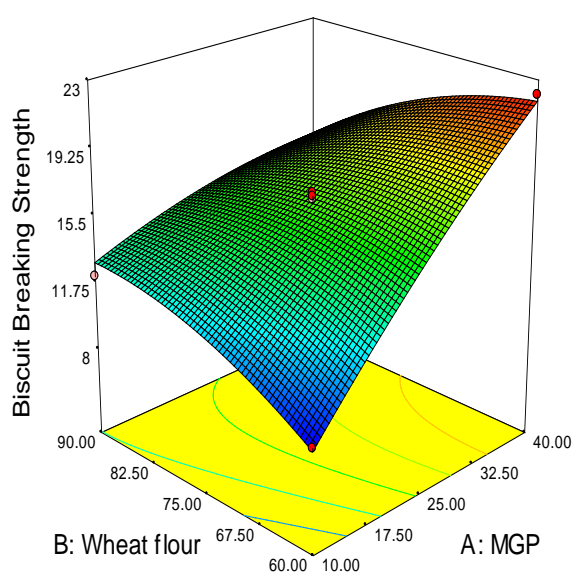

(f)

Figure 2. 3D plot depicting the effect of MGP (\%) and wheat flour (\%): (a) Protein (\%); (b) Soluble fiber (\%); (c) Insoluble fiber (\%); (d) OAA; (e) Dough hardness; and (f) Breaking strength of biscuits. 
shows the effect of MGP on the responses viz. protein, soluble fibre and insoluble fibre contents. Earlier, [29] optimized cereal-millet based nutri-bar and reported the significant increase in protein, fat, fiber and ash content.

Biscuit dough hardness and breaking strength are important physical parameters in the biscuit quality evaluation, which in turn affect the sensory attributes of biscuits. Figure 2(e) and Figure 2(f) show the effect of MGP on dough hardness and biscuit breaking strength respectively. The hardness of the dough increased with the increase in MGP addition [30]. The increase in the dough hardness may be due to presence of greater number of hydroxyl groups, which exist in the fiber structure of MGP, allows more water interaction through hydrogen bonding [31]. The breaking strength of biscuits increased with the incorporation of MGP. This breaking strength stimulates the evaluation of hardness by consumer holding the biscuits in hands and breaking by bending [32]. Similar finding of increased breaking strength of biscuits by adding fenugreek seed and flax seed was reported [33]. Sensory attributes plays an important role in modification, improvement, development and acceptance of new food products [14]. Figure 2(d) depicts the effect of variables on OAA of biscuits, which reduced significantly ( $\leq$ 0.05) with the incorporation of MGP. Earlier, [10] also reported reduction in OAA score of biscuits with the $30 \%$ addition of roasted, steamed or microwave treated wheat bran. Addition of increased level of rice bran and fenugreek flour blends decreased the OAA scores of cookies [34].

\subsection{Regression Equations and Model Fitting}

Regression coefficients, $\mathrm{R}^{2}$, adjusted $\mathrm{R}^{2}$ and probability (p) values for the protein and dietary fibre enriched biscuits were developed and presented in the Table 3 . All the responses were fitted with quadratic models. The $\mathrm{p}$ values of all regression models were less than 0.0310 indicating the significance of all the models. The $\mathrm{R}^{2}$ values of the responses to protein, soluble fibre, insoluble fibre, dough hardness, biscuit breaking strength and OAA were found to be $0.9847,0.9796,0.9976,0.9694,0.9837$ and 0.9635 respectively, which is higher than $80 \%$ indicating the fitness of polynomial models used for describing the effect of variables on the responses [35]. Earlier [14] reported, in optimization of baking parameters of chapathi with respect to vitamin B1 and B2 retention and quality, the polynomial models were fitted as the $\mathrm{R}^{2}$ value for the responses like hardness, cohesiveness, chewiness, vitamin B1 and B2 were above $80 \%$.

The multiple regression equations (in terms of coded factors) were obtained for the responses are as follows;

$$
\begin{aligned}
& \begin{array}{c}
\text { Protein (\%) } Y=+12.09+0.38 * A-0.91 * B-0.14 * A * B-0.68 * A^{2}+0.35 * B^{2} \\
-1.120 E-003 * A^{2} * B+3.54 * A * B^{2}
\end{array} \\
& \text { Soluble fibre (\%) } Y=+1.45+0.72 * A-0.20 * B-0.090 * A * B-0.095 * A^{2}+0.15 * B^{2} \\
& \text { Insoluble fibre (\%) } Y=+4.86+1.87 * A-0.59 * B-0.20 * A * B-0.53 * A^{2}-0.26 * B^{2}
\end{aligned}
$$

\begin{tabular}{|c|c|c|c|c|c|c|}
\hline \multirow[t]{2}{*}{ Term } & \multicolumn{6}{|c|}{ Responses } \\
\hline & Protein (\%) & $\begin{array}{c}\text { Soluble } \\
\text { fibre (\%) }\end{array}$ & $\begin{array}{l}\text { Insoluble } \\
\text { fibre (\%) }\end{array}$ & $\begin{array}{c}\text { Dough } \\
\text { hardness }(\mathrm{N})\end{array}$ & $\begin{array}{l}\text { Biscuit breaking } \\
\text { strength }(\mathrm{N})\end{array}$ & OAA \\
\hline$F$ value & 89.82 & 67.18 & 592.14 & 44.29 & 84.56 & 36.94 \\
\hline$P>F$ & 0.0001 & $<0.0001$ & $<0.0001$ & $<0.0001$ & $<0.0001$ & $<0.0001$ \\
\hline Mean & 11.89 & 1.48 & 4.38 & 318.63 & 15.50 & 8.22 \\
\hline Standard deviation & 0.55 & 0.12 & 0.11 & 10.07 & 0.64 & 0.076 \\
\hline$R$ squared & 0.9847 & 0.9796 & 0.9976 & 0.9694 & 0.9837 & 0.9635 \\
\hline Adjusted $R$ squared & 0.9737 & 0.9650 & 0.9960 & 0.9475 & 0.9721 & 0.9374 \\
\hline Predicted $R$ squared & 0.9060 & 0.8797 & 0.9875 & 0.8118 & 0.9001 & 0.7808 \\
\hline Adequate precision & 31.032 & 28.15 & 77.613 & 22.400 & 30.812 & 19.989 \\
\hline
\end{tabular}

Table 3. Regression coefficient and model statistics for high protein and dietary fibre enriched biscuits. 
Overall acceptability $(O A A) Y=+8.18-0.32 * A+0.13 * B-0.025 * A * B+0.10 * A^{2}-0.046 * B^{2}$

Dough hardness $(N) Y=+333.65+47.58 * A+6.46 * B-20.29 * A * B-6.37 * A^{2}-18.05 * B^{2}$

Biscuit breaking strength $(N) Y=+16.56+4.09 * A-0.36 * B-2.57 * A * B-0.64 * A^{2}-1.07 * B^{2}$

\subsection{Optimization of MGP Level and Model Validation}

The ratio of MGP and wheat flour for biscuits was optimized using numerical multi-response optimization method. Numerical optimization technique is one of the best methods to find out the best optimal ratio of the variables as it reduces the time and efforts required for the investigation of multifactor and multiple-response systems. The optimized ratio of MGP and wheat flour was $40 \%$ and $60 \%$ respectively, with a desirability of 0.991 . The predicted responses were experimentally validated using an optimized ratio of MGP and wheat flour (Table 4). A model can be considered as an adequate model, if the predicted values are close to the experimental values observed during the validation tests [36]. The results revealed that there is no significant $(p \leq 0.05)$ difference between experimental and predicted response values and thereby reconfirming the adequacy of the models.

\subsection{Proximate Composition of Control and Optimized Biscuit}

The composition of optimized and control biscuits were presented in Table 5. The addition of MGP did not affect significantly the fat content of biscuits, but a significant $(\mathrm{p} \leq 0.05)$ difference in protein, soluble and insoluble fiber content was observed. The protein content, soluble fibre, insoluble fibre contents were found to increase from $7.7 \%, 0.46 \%$ and $2.17 \%$ to $16.61 \%, 2.57 \%$ and $6.67 \%$ respectively. Earlier, [9] reported up to $15 \%$ addition of multigrain mix in bread making resulted in a $1.5 \%$ increase in protein and $2.5 \%$ increase in dietary fiber.

\section{Conclusion}

RSM was found to be efficient in optimizing the best optimal ratio of MGP and wheat flour to obtain protein and dietary fibre enriched biscuits. The present study shows that if wheat flour is substituted with $40 \%$ of MGP developed by using sorghum, barley, chickpea, pea and defatted soya flour each at $20 \%$ level, it is good enough to produce biscuits containing high protein (16.61\%) and dietary fibre (9.24\%) with a good overall acceptability similar to wheat flour based control biscuits.

Table 4. Predicted and experimental value for the responses at optimum conditions.

\begin{tabular}{ccccccc} 
& Protein (\%) & Soluble fibre (\%) & Insoluble fibre (\%) & $\begin{array}{c}\text { Dough } \\
\text { hardness (N) }\end{array}$ & $\begin{array}{c}\text { Biscuit breaking } \\
\text { strength (N) }\end{array}$ & OAA (9) \\
\hline Predicted & 16.79 & 2.51 & 6.73 & 370.65 & 21.86 & 7.82 \\
Experimental & 16.61 & 2.57 & 6.67 & 365.17 & 21.36 & 7.9 \\
\hline
\end{tabular}

Table 5. Proximate compositions of MGP, control and optimized biscuits.

\begin{tabular}{|c|c|c|c|}
\hline Proximate composition (\%) & Multigrain premix & Control biscuit & Optimized biscuit \\
\hline Moisture & $8.13 \pm 0.09$ & $3.71 \pm 0.07$ & $3.76 \pm 0.13$ \\
\hline Ash & $3.46 \pm 0.007$ & $0.91 \pm 0.08$ & $1.51 \pm 0.07$ \\
\hline Protein & $26.28 \pm 0.18$ & $7.7 \pm 0.22$ & $16.61 \pm 0.37$ \\
\hline Fat & $3.18 \pm 0.18$ & $14.48 \pm 0.15$ & $14.46 \pm 0.28$ \\
\hline Soluble dietary fibre & $7.38 \pm 0.6$ & $0.46 \pm 0.21$ & $2.57 \pm 0.29$ \\
\hline Insoluble dietary fibre & $10.13 \pm 0.08$ & $2.17 \pm 0.11$ & $6.67 \pm 0.19$ \\
\hline Energy $(\mathrm{k} \cdot \mathrm{Cal})$ & $369.54 \pm 0.39$ & $452.59 \pm 0.37$ & $451.22 \pm 0.42$ \\
\hline
\end{tabular}




\section{Acknowledgements}

The authors are sincerely thankful to DRDO_-Defence Food Research Laboratory for their help to carry out this research work.

\section{References}

[1] Chavan, J.K. and Kadam, S.S. (1993) Nutritional Enrichment of Bakery Products by Supplementation with Non-Wheat Flours. Critical Reviews in Food Science and Nutrition, 33, 189-226. http://dx.doi.org/10.1080/10408399309527620

[2] Banerjee, C., Singh, R., Jha, A. and Mitra, J. (2014) Effect of Inuline on Textural and Sensory Characteristics of Sorghum Based High Fibre Biscuits Using Response Surface Methodology. Journal of Food Science Technology, 51, 27622768.

[3] Abu-Salem, F.M. and Abou-Arab, A.A. (2011) Effect of Supplementation of Bambara Groundnut (Vigna subterranean L.) Flour on the Quality of Biscuits. African Journal of Food Science, 5, 376-383.

[4] Sudha, M.L., Vetrimani, R. and Leelavathi, K. (2007) Influence of Fibre from Different Cereals on the Rheological Characteristics of Wheat Flour Dough and on Biscuit Quality. Food Chemistry, 100, 1365-1370. http://dx.doi.org/10.1016/j.foodchem.2005.12.013

[5] Jyotsna, R., Shwetha, L., Jyothilakshmi, A. and Venkateshwara, R.G. (2012) Influence of Green Gram Flour (Phaseolus aureus) on the Rheology, Microstructure and Quality of Cookies. Journal of Texture Studies, 43, 350-360. http://dx.doi.org/10.1111/j.1745-4603.2012.00346.X

[6] Ritika, B.Y., Baljeet, S.Y. and Nisha, D. (2012) Effect of Incorporation of Plantain and Chickpea Flours on the Quality Characteristics of Biscuits. Journal of Food Science and Technology, 49, 207-213. http://dx.doi.org/10.1007/s13197-011-0271-x

[7] Stauffer, C.E. (1990) Emulsifiers and Dough Strengtheners in Functional Additives for Bakery Foods. Van Nostrand Reinhold, New York, 69-124.

[8] Izydorczyk, M.S. and Dexter, J.E. (2008) Barley b-Glucans and Arabinoxylans: Molecular Structure, Physicochemical Properties, and Uses in Food Products-A Review. Food Research International, 41, 850-868. http://dx.doi.org/10.1016/j.foodres.2008.04.001

[9] Indrani, D., Soumya, C., Jyotsna, R. and Venkateshwara, R.G. (2010) Multigrain Bread-Its Dough Rheology, Microstructure, Quality and Nutritional Characteristics. Journal of Texture Studies, 41, 302-319. http://dx.doi.org/10.1111/j.1745-4603.2010.00230.x

[10] Nandeesh, K., Jyotsna, R. and Rao, G.V. (2011) Effect of Differently Treated Wheat Bran on Rheology, Microstructure and Quality Characteristics of Soft Dough Biscuits. Journal of Food Processing and Preservation, 35, 179-200. http://dx.doi.org/10.1111/j.1745-4549.2009.00470.x

[11] Okpala, L.C. and Okoli, E.C. (2011) Formulation and Evaluation of Cookies Containing Germinated Pigeon Pea, Fermented Sorghum and Cocoyam Flour Blends Using Mixture Response Surface Methodology. Advance Journal of Food Science and Technology, 3, 366-375.

[12] Rai, P., Majumdar, G.C., Gupta, S.D. and De, S. (2004) Optimizing Pectinase Usage in Pretreatment of Mosambi Juice for Clarification by Response Surface Methodology. Journal of Food Engineering, 64, 397-403. http://dx.doi.org/10.1016/j.jfoodeng.2003.11.008

[13] Sun, Y., Wang, Z.F., Wu, J.H., Chen, F., Liao, X.J. and Hu, X.S. (2006) Optimizing Enzymatic Maceration in Pretreatment of Carrot Juice Concentrates by Response Surface Methodology. International Journal of Food Science and Technology, 41, 1082-1089. http://dx.doi.org/10.1111/j.1365-2621.2006.01182.x

[14] Yadav, D.N., Sharma, G.K. and Bawa, A.S. (2007) Optimization of Soy Fortified Instant Sooji Halwa Mix Using Response Surface Methodology. Journal of Food Science and Technology, 44, 297-300.

[15] Nazni, P. and Gracia, J. (2014) Optimization of Fibre Rich Barnyard Millet Bran Cookies Using Response Surface Methodology. International Journal of Agriculture and Food Science, 4, 100-105.

[16] Reddy, J.K., Pandey, M.C., Harilal, P.T. and Radhakrishna, K. (2013) Optimization and Quality Evaluation of Freeze Dried Mutton Manchurian. International Food Research Journal, 20, 3101-3106.

[17] Kathiravan, T., Nadanasabapathi, S. and Kumar, R. (2013) Optimization of Pulsed Electric Field Processing Conditions for Passion Fruit Juice (Passiflora edulis) Using Response Surface Methodology. International Journal of Advanced Research, 1, 399-411.

[18] AACC International (2000) Approved Methods of the Association of Cereal Chemists International. 10th Edition, AACC International, Saint Paul.

[19] Asp, N.G., Johabsson, C.G., Hallmer, H. and Siljestrom, M. (1983) Rapid Enzymatic Assay of Insoluble and Soluble 
Dietary Fibre. Journal of Agriculture and Food Chemistry, 31 476- 482. http://dx.doi.org/10.1021/jf00117a003

[20] Myers, R.H. and Montegomery, D.C. (2002) A Text Book of "Response Surface Methodology: Process and Product Optimization Using Design Experiments”. 2nd Edition, John Wiley \& Sons Inc., Hoboken, 321-342.

[21] Montgomery, D.C. (2001) Design and Analysis of Experiments. John Wiley and Sons, New York.

[22] Sin, H.N., Yusof, S., Hamid, N.S.A. and Rahman, R.A. (2006) Optimization of Hot Water Extraction for Sapodilla Juice Using Response Surface Methodology. Journal of Food Engineering, 74, 352-358. http://dx.doi.org/10.1016/j.jfoodeng.2005.03.005

[23] Bourne, M.C. (1978) Texture Profile Analysis. Food Technology, 32, 62-66.

[24] Gains, C.S. (1991) Instrumental Measurement of the Hardness of Cookies and Crackers. Cereal Foods World, 36, 989, 991-994, 996.

[25] Larmond, E. (1997) Laboratory Methods for Sensory Evaluation of Foods. Canada Department of Agriculture Publication, Ottawa.

[26] Dachana, K.B., Jyotsna, R., Indrani, D. and Prakash, J. (2010) Effect of Dreid Moringa (Moringa oleiferal Lam.) Leaves on Rheological, Microstructural, Nutritional, Textural and Organoleptic Characteristics of Cookies. Journal of Food Quality, 33, 660-677. http://dx.doi.org/10.1111/j.1745-4557.2010.00346.x

[27] Aleem, Z.M.D., Genitha, T.R. and Syed, I.S. (2012) Effects of Defatted Soy Flour Incorporation on Physical, Sensorial and Nutritional Properties of Biscuits. Journal of Food Process and Technology, 3, 4.

[28] Awika, M.J. and Rooney, L.W. (2004) Sorghum Phytochemicals and Their Potential Impact on Human Health. Phytochemistry, 65, 1199-1221. http://dx.doi.org/10.1016/j.phytochem.2004.04.001

[29] Poongodi, V.T., Raghunath, T. and Jaganmohan, R. (2012) Preparation of Cereal Mix for Nutri-Composite Bar Development Using Response Surface Methodology. Elixir Food Science, 53, 11946-11950.

[30] Banerjee, C., Singh, R., Jha, A. and Mitra, J. (2014) Effect of Inuline on Textural and Sensory Characteristics of Sorghum Based High Fibre Biscuits Using Response Surface Methodology. Journal of Food Science Technology, 51, 27622768.

[31] Rosell, C.M., Rojas, J.A. and Benedito, B. (2001) Influence of Hydrocolloids on Dough Rheology and Bread Quality. Food Hydrocolloids, 15, 75-81. http://dx.doi.org/10.1016/S0268-005X(00)00054-0

[32] Devi, K. and Haripriya, S. (2012) Pasting Behavior of Starch and Protein in Soy Flour Enriched Composite Flours on Quality of Biscuits. Journal of Food Processing and Preservation, 38, 116-124. http://dx.doi.org/10.1111/j.1745-4549.2012.00752.x

[33] Nirmala, M., Jyotsna, R., Jeyarani, T. and Rao, G.V. (2011) Influence of Debittered, Defatted Fenugreek Seed Powder and Flax Seed Powder on the Rheological Characteristics of Dough and Quality of Cookies. International Journal of Food Science and Nutrition, 62, 336-344. http://dx.doi.org/10.3109/09637486.2010.536145

[34] Sharma, H.R. and Chauhan, G.S. (2002) Effects of Stabilized Rice Bran-Fenugreek Blend on the Quality of Breads and Cookies. Journal of Food Technology, 39, 225-233.

[35] Joglekar, A.M. and May, A.T. (1987) Product Excellence through Design of Experiments. Cereal Foods World, 32, 857-868.

[36] Madamda, P.S. (2002) The Response Surface Methodology: An Application to Optimize Dehydration Operations of Selected Agricultural Crops. Lebensmittel-Wissenschaft and Technolgie, 35, 584-592. 